\title{
Unravelling Attribution, Control and Jurisdiction: Some Reflections on the Case Law of the European Court of Human Rights
}

\section{Remy Jorritsma*}

\section{Introduction}

This contribution provides a reflection on case law of the European Court of Human Rights (the Court) dealing with issues of attribution, control and jurisdiction in interpreting and applying the European Convention on Human Rights ${ }^{1}$. The cases that have touched upon these questions constitute a patchwork of jurisprudence. It has been difficult to discern any underlying systematic approach, in particular when the relevant claims concern the alleged responsibility of a State for conduct outside its national territory. The ultimate aim of this contribution is to provide more clarity through an analysis of the interaction between the substantive law as found in the Convention, rules of attribution as found in the law of State responsibility, and the availability of procedural avenues of redress for victims with respect to the enforcement of obligations arising out of the Convention. As will be shown below, analytically speaking the law of State responsibility, the existence and exercise of a State's jurisdiction, and the jurisdiction of the Court are separate issues, each governed by their own rules of international law. However, their separate and conceptually distinct nature does not preclude these issues from relating to each other or having a certain consequential influence over each other.

This contribution will first contextualize a number of methodological difficulties and relevant legal terms, i.e. jurisdiction, control and attribution (Section I). This is followed by an examination of these terms separately in light of the relevant rules of public international law (Sections IIIV). The last substantive section (Section V) ties these concepts back to-

* Research Fellow at the Max Planck Institute Luxembourg for Procedural Law.

1 Convention for the Protection of Human Rights and Fundamental Freedoms, 4 November 1950, 213 UNTS 222, ETS 5 (as amended by Protocol 14) (Convention, or ECHR). 
gether again and analyzes the function that attribution rules play (or are perceived to play by the Court) in the scheme of all of this.

\section{In Search of a Sound Methodology for the Determination of State Responsibility in Extraterritorial Situations}

States and non-State actors have the potential to pose an enormous threat to the enjoyment of human rights of individuals. Globalization and privatization have resulted in a wider theatre of operations for States and an increased reliance by States on non-State actors for carrying out sovereign State functions or pursuing State policies. ${ }^{2}$ For individuals in Europe, the Convention offers a unique mechanism to address alleged human rights violations arising out of such situations. It involves a judicial procedure with direct access for individual victims, entailing binding judgments and a built-in enforcement mechanism under the aegis of the Council of Europe.

The Court does not always present clear legal solutions in terms of holding a State responsible under the Convention for its actions or for those of non-State actors, especially if the State is alleged to be responsible for conduct outside its national borders. ${ }^{3}$ To some extent, the rather unsystematic and haphazard approach of the Court may be explained by the fact that certain highly relevant terms of art have different meanings depending on the context in which they are used. For example, the notion of control plays a role in assessing whether pursuant to Article 8 of the International Law Commission's Articles on Responsibility of States for Internationally Wrongful Acts ${ }^{4}$ (ARSIWA) the behaviour of a non-State actor can be at-

2 The roles of privatization and globalization and their impact on the prominence of non-State actors in international law have been widely commented on in the literature. See among many sources e.g. International Law Association Committee on Non-State actors (2005-2016), Final Report, Johannesburg Conference (2016), available at www.ila-hq.org/index.php/committees. [All URLs in this contribution were last visited 30 April 2018].

3 On extraterritorial application of human rights treaties, see e.g. F. Coomans and M.T. Kamminga (eds.), Extraterritorial Application of Human Rights Treaties (2004); M. Gondek, The Reach of Human Rights in a Globalising World: Extraterritorial Application of Human Rights Treaties (2009); M. Milanović, Extraterritorial Application of Human Rights Treaties: Law, Principles, and Policy (2011); K. da Costa, The Extraterritorial Application of Selected Human Rights Treaties (2012).

4 The text of the Articles and accompanying commentaries are reproduced in J. Crawford, The International Law Commission's Articles on State Responsibility: Introduction, Text and Commentaries (2002). 
tributed to a State. Yet, the term of control is also used to determine whether a victim is protected by the substantive rights and freedoms pursuant to Article 1 of the Convention. The term jurisdiction, in turn, may refer to the above-mentioned reach of substantive obligations imposed by the Convention on a State or alternatively to the competence of the Court to take cognizance of complaints alleging violations of these rules.

Another cause of the lack of clarity and predictability in the Court's reasoning with respect to the extraterritorial application of the Convention and situations involving non-State actors is that the Court tends to judge such cases on a need-to-decide basis. In his lengthy, articulate concurring opinion in Al-Skeini, for example, Judge Bonello laments that the judicial decision-making process in Strasbourg suffers in some ways from internal contradiction and that it has "squandered more energy in attempting to reconcile the barely reconcilable than in trying to erect intellectual constructs of more universal application". ${ }^{5}$ Indeed, while the Court generally makes a point in recalling its earlier jurisprudence, it often does so in a way that creates the false impression that the case at hand fits perfectly in the body of earlier precedents. Moreover, it may not always be clear in the Court's reasoning whether for the application of the Convention abroad, or the attribution to a State of certain conduct, a particular set of circumstances such as control over persons or territory is deemed sufficient (leaving open the possibility that other, less-demanding levels of control may do the trick as well) or rather per se necessary (in which case the identified level of control decisively represents a minimum-level; a conditio sine quae non).

As Dominic McGoldrick observed on this topic, the correct methodology "will determine what are the right questions and the right answers [and] that what appear to be the right answers are superficially attractive but they are answering the wrong questions" 6 The present author would like to add that not only are the right questions important but also the correct order in which the Court poses them, the clarity of steps taken in judicial reasoning, as well as consistency in application. It would be expected that the Court, as any judicial dispute settlement body, undertake its function as guardian of the law in a clear, steady, predictable and logical manner. This is important not only from a substantive point of view when trying to

5 Al-Skeini and Others v. the United Kingdom, ECtHR Application No. 55721/07, Judgment of 7 July 2011 [GC], Concurring Opinion of Judge Bonello, para. 7.

6 D. McGoldrick, Extraterritorial Application of the International Covenant on Civil and Political Rights, in Coomans and Kamminga, supra note 3, 41, 42. 
analyze the case law by identifying similarities and patterns but also - arguably even more so - from a procedural point of view given that the lack of clarity and predictability regarding the issues addressed in this contribution may thwart access to justice and remedies for actual or potential victims of violations of the Convention.

\section{Jurisdiction of the European Court of Human Rights}

In international adjudication, the term jurisdiction refers to the question whether a court or tribunal can entertain a case and render a binding decision. $^{7}$ The scope of a court or tribunal's jurisdiction is invariably regulated and circumscribed by its constituent instrument. In the European system of human rights protection, the Court has jurisdiction to interpret and apply the Convention, in particular in disputes brought to its attention by State parties (i.e. inter-State cases), or by any person, nongovernmental organization or group of individuals claiming to be a victim of a violation of the ECHR (i.e. individual applications). ${ }^{8}$ Before proceeding with the merits of a case, it must first be ascertained that the case is admissible under the terms of Article 35 ECHR. If (or to the extent that) an application is inadmissible, the Court will not have jurisdiction to examine it in substance and the case would not be allowed to proceed further. ${ }^{9}$ According to Article 35(3)(a), the Court shall declare inadmissible - and thus cease its exercise of jurisdiction with respect to - any application that, inter alia, "is incompatible with the provisions of the Convention or the Protocols" ${ }^{10}$

Two grounds of inadmissibility (or incompatibility) are important for this contribution. First, a case is inadmissible if there is a lack of jurisdiction ratione personae, for example, because the conduct complained of can-

7 S. Rosenne, 'International Courts and Tribunals, Jurisdiction and Admissibility of Inter-State Applications' (last updated March 2006), Max Planck Encyclopedia of Public International Law, available at http://opil.ouplaw.com/home/EPIL, para. 2.

8 Articles 32-34 ECHR.

9 Applications can be declared inadmissible in any stage of the proceedings; see Article 35(4) ECHR.

10 Article 35 ECHR formally applies to individual applications only. The Court has held that "this cannot prevent the Court [in inter-State cases] from establishing already at [the] preliminary stage, under general principles governing the exercise of jurisdiction by international tribunals, whether it has any competence at all to deal with the matter laid before it"; see Georgia v. Russia (II), ECtHR Application No. 38263/08, Decision of 13 December 2011, para. 64. 
not be attributed to a State party. ${ }^{11}$ And second, a case will be held inadmissible if the Court finds that there is a lack of jurisdiction ratione loci, meaning that the victim is not within a State party's jurisdiction in the sense of Article 1 ECHR. ${ }^{12}$ Article 35 ECHR thus brings together questions of attribution of conduct to a State and the existence of State jurisdiction in terms of Article 1, requiring that both conditions be fulfilled for the Court to be able to exercise its jurisdiction and consider the merits of a case.

\section{Attribution of Conduct to a State}

The legal process of attribution in international human rights law looks into the connection that exists between the State that is claimed to be internationally responsible and the author of the act that is alleged to violate the victim's human rights. The rules on State responsibility as codified in ARSIWA provide that an internationally wrongful act occurs when conduct "(a) is attributable to the State under international law; and (b) constitutes a breach of an international obligation of the State".13 The Court has called this definition the "cornerstone of State responsibility under international law". ${ }^{4}$ The law of State responsibility is said to form a framework of secondary rules and purportedly does not address or regulate the content, interpretation or application of primary (or substantive) rules of international law such as the rights and freedoms laid down in the Convention. As put by Roberto Ago: "[I]t is one thing to define a rule and the content of the obligation it imposes and another to determine whether that obligation has been violated and what should be the consequences of the violation. Only the second aspect comes within the sphere of responsibility proper." 15

The rules of attribution in Part One, Chapter Two (i.e. Articles 4-11) of ARSIWA distinguish private acts from those which can be genuinely re-

11 Council of Europe, Practical Guide on Admissibility Criteria (updated 30 April 2018), paras. 185 and 199, available at www.echr.coe.int (Case-law - Case-law analysis - Admissibility Guide) [CoE Admissibility Guide].

12 Ibid., paras. 209-211.

13 Articles 1 and 2 ARSIWA.

14 Likvidējamā P/S Selga and Vasilevska v. Latvia, ECtHR Applications Nos. 17126/02 and 24991/02, Decision of 1 October 2013, paras. 95 and 64-65.

15 Second Report on State Responsibility (by Robert Ago, Special Rapporteur) The Origin of International Responsibility, 2 ILC Yearbook (1970) 178, para. 7. 
garded as acts of the State. These provisions are widely considered to represent customary international law. ${ }^{16}$ In principle, a State can only be held responsible for the conduct (i.e. acts and omissions) of those persons and entities which make up the State's institutional apparatus. Consequently, Article 4 ARSIWA provides that the conduct of a State's organs (this includes local authorities) is attributable to the State. ${ }^{17}$ Article 4 appears to cover not only those persons or entities considered by a State's internal law as its de jure organs but also a State's de facto organs, i.e. those persons or entities who, while not having the formal status of State organ, are equated with such on the basis of a relationship with the State which the International Court of Justice in Bosnian Genocide described as "complete dependence". ${ }^{18}$ What matters here is whether the non-State actor is a mere instrument through which the State acts, lacking any real autonomy, and whether there is a "particularly great degree of State control" akin to what a State ordinarily exercises over its organs. ${ }^{19}$ Or, as the International Court of Justice held earlier in Nicaragua, it depends "on the extent to which the [State] made use of the potential for control inherent in that dependence". ${ }^{20}$ Likewise attributable to a State is the conduct of persons or entities empowered by it to exercise governmental authority, ${ }^{21}$ or that of State organs placed at its disposal by another State. ${ }^{22}$ In each of these cases, it makes no difference that the organ or entity acts ultra vires; its conduct will

16 See e.g. the numerous references to ARSIWA's attribution rules as documented in the UN Secretary-General's reports containing a compilation of decisions of international courts, tribunals and other bodies, in UN Doc A/62/62 (1 February 2007) and Add.1 (17 April 2007), UN Doc A/65/76 (30 April 2010), UN Doc A/68/72 (30 April 2013), and UN Doc A/71/80 (21 April 2016). See also Materials on the responsibility of states for internationally wrongful acts, UN Doc ST/LEG/SER B/25 (2012), 27-124; S. Olleson, State Responsibility before International and Domestic Courts: The Impact and Influence of the ILC Articles (forthcoming; preliminary draft available at www.biicl.org/files/3107_impactofthearticlesonstate_responsibilitypreliminarydraftfinal.pdf).

17 Article 4 ARSIWA.

18 Application of the Convention on the Prevention and Punishment of the Crime of Genocide (Bosnia and Herzegovina v. Serbia and Montenegro), Judgment (Merits), ICJ Reports 2007, 43, 205, para. 392.

19 Ibid., para. 393.

20 Military and Paramilitary Activities in and against Nicaragua (Nicaragua v. USA), Judgment (Merits), ICJ Reports 1986, 14, 62, para. 110.

21 Article 5 ARSIWA.

22 Article 6 ARSIWA. 
be considered as an act of the State at least insofar as it is undertaken in actual or apparent official capacity. ${ }^{23}$

The corollary of the rule that a State can only be held responsible for its own conduct is that the conduct of private persons is in principle not attributable to the State. This is illustrated very well by the Tagayeva case. The applicants in this case complained that Russia was responsible for their treatment while being held captive by terrorists during the 2004 Beslan hostage crisis in North-Ossetia, Russia. The Court in Strasbourg held that while Russia could be held responsible for its own acts (i.e. the operation to liberate the hostages), and for its omissions in relation to the terrorists (i.e. indirect responsibility as a result of a failure to act in violation of a State's positive obligations), it could not be established that Russia bore any direct responsibility for the acts of the terrorists as the latter's acts could not be considered as attributable to it. Relying on the Commentary to Chapter II of ARSIWA, the Court explained that "the conduct of private persons is not as such attributable to the State" and that "human rights violations committed by private persons are outside of the Court's competence ratione personae".24

However, there may be special circumstances such as the existence of a specific factual relationship between the State and the individual, ${ }^{25}$ where international law nevertheless regards private conduct as acts of the State. The remainder of Part One, Chapter Two sets out when this is the case. For example, under Article 8 ARSIWA the conduct of a non-State acting under the "direction or control" of a State is attributable to the latter. ${ }^{26}$ When it comes to the exact level of control required by Article 8 international courts and tribunals have adopted divergent positions. In Bosnian Genocide the International Court of Justice required proof of effective control, meaning control exercised "in respect of each operation in which the alleged violations occurred, not generally in respect of the overall actions" taken by

\section{Article 7 ARSIWA.}

24 Tagayeva and Others v. Russia, ECtHR Application No. 26562/07, Decision of 9 June 2015, para. 581.

25 Commentary to Article 8 ARSIWA, in Crawford, supra note 4, 110, para. 1.

26 Article 8 ARSIWA. The remaining grounds for attribution - Article 9 dealing with conduct in the absence of governmental authorities, Article 10 on insurrectional movements, and Article 11 on conduct acknowledged and adopted by the State - will not be addressed in this contribution, as they are in practice quite exceptional and the Court has never relied on them in its case law. 
the non-State actor in question. ${ }^{27}$ Case law of the International Criminal Tribunal for the former Yugoslavia agrees with effective control being the proper test for attribution under State responsibility law but as an exception it considers the less-demanding test of overall control appropriate when the non-State actor is an organized armed group involved in an armed conflict. It defines overall control as "more than the mere provision of financial assistance or military equipment or training [but without the need to show] the issuing of specific orders by the State, or its direction of each individual operation" ${ }^{28}$ It has been submitted that it is rather unclear how the level of control required for the purposes of Article 8 ARSIWA differs from that articulated by the International Court of Justice in Bosnian Genocide with respect to completely dependent de facto organs purportedly covered by Article 4 ARSIWA. ${ }^{29}$

The Articles apply to the whole range of international obligations of States regardless of whether the obligation is owed to one or several other States or to individual persons. ${ }^{30}$ It follows that the attribution rules as laid down in ARSIWA also apply to the establishment of State responsibility within the regime of international and regional human rights law. An internationally wrongful act is an indispensable condition for a State to be held responsible and reliance on the rules of attribution from Part One form part of that exercise regardless of the identity of the claimant. Indeed, when questions of attribution arise the Court occasionally refers to ARSIWA. For example, in Kotov, when describing the law relevant to attribution the Court referred to ARSIWA as "codified principles developed in modern international law in respect of the State's responsibility for internation-

27 Bosnian Genocide, supra note 18, para. 400. See also United States Diplomatic and Consular Staff in Tehran (United States of America v. Iran), Judgment, ICJ Reports 1980, 3, 29, para. 58; Nicaragua, supra note 20, 14, 64, para. 115; Armed Activities on the Territory of the Congo (DRC v. Uganda), Judgment, ICJ Reports 2005, 168, 226, para. 160.

28 Prosecutor v. Tadić, IT-94-1A, Appeals Chamber, Judgment of 15 July 1999, para. 137. The Tribunal has repeatedly confirmed and applied this test, up to its very final appeals judgment, see Prosecutor v. Prlić et al., IT-04-74-A, Appeals Chamber, Judgment of 29 November 2017, paras. 238 and 246.

29 B. Stern, The Elements of an Internationally Wrongful Act, in J. Crawford et al., The Law of International Responsibility (2010), 193, 206.

30 General commentary to ARSIWA, in Crawford, supra note 4, 76, para. 5. See further Commentary to Article 33, ibid., 210, para. 4. See also Article 12 ARSIWA, which provides in general terms that a breach of a State's international obligation can occur "regardless of its origin or character". 
ally wrongful acts" ${ }^{31}$ It must be noted, though, that in the vast majority of cases the Court does not expressly cite the attribution provisions of ARSIWA. ${ }^{32}$ This applies both to the final version as adopted on second reading in 2001 as well as the various attribution rules as provisionally adopted on first reading in the period 1973-1975. This is partly due to the fact that in most cases there can be no doubt that the acts of the involved governmental actor - such as national courts, regular armed forces, or the police - are attributable to the State. ${ }^{33}$ At times, the Court also applies rules and principles which underpin ARSIWA but without explicitly mentioning the latter by name. ${ }^{34}$

The justification for relying on rules of (conventional or) customary international law found outside of the Convention can be explained by the principle of systemic integration which holds that treaties must be interpreted by taking into account any relevant rules of international law applicable in the relations between the parties. ${ }^{35}$ It was this provision that led a Grand Chamber to conclude that the "principles underlying the Convention cannot be interpreted and applied in a vacuum", and that the Court must also take into account "any relevant rules of international law when examining questions concerning its jurisdiction and, consequently, determine State responsibility in conformity with the governing principles of international law" ${ }^{36}$ Accordingly, the Convention should be interpreted as

31 Kotov v. Russia, ECtHR Application No. 54522/00, Judgment of 3 April 2012 [GC], paras. 30-32.

32 R. Lawson, Out of Control: State Responsibility and Human Rights - Will the ILC's Definition of the "Act of State" Meet the Challenges of the 21st Century?, in M. Castermans-Holleman, F. van Hoof and J. Smith (eds.), The Role of the Nation-State in the 21st Century: Human Rights, International Organizations and Foreign Policy - Essays in Honour of Peter Baehr (1998), 91, 115.

33 M. Milanović, 'Jurisdiction and Responsibility: Trends in the Jurisprudence of the Strasbourg Court' (2016), available at http://papers.ssrn.com/sol3/papers.cfm?abstr act_id=2753544, 9-10.

34 See e.g. Krastanov v. Bulgaria, ECtHR Application No. 50222/99, Judgment of 30 September 2004, paras. 53-54, where the Court held that Bulgaria, acting through its police officers in the performance of their duties, had violated the substantive limb of Article 3 of the Convention. In its judgment the Court did not make any such reference, but the outcome in terms of attribution is fully in line with Article 4 and Article 7 ARSIWA.

35 Article 31(3)(c) Vienna Convention on the Law of Treaties, 23 May 1969, 1155 UNTS 331.

36 Banković and Others v. Belgium and 16 Other High Contracting Parties, ECtHR Application No. 52207/99, Decision of 12 December 2011 [GC], para. 57 (references omitted). 
far as possible in harmony with other principles of international law of which it forms part.

Notwithstanding the interpretive value of the principle of systemic integration, however, the Court must be mindful of the fact that the Convention is not an ordinary multilateral treaty. The Court has repeatedly held that in its interpretation it must "have regard to the special character of the Convention as a treaty for the collective enforcement of human rights and fundamental freedoms", ${ }^{37}$ and that the Convention is "a constitutional instrument of European public order (ordre public)" 38 These considerations point towards the possibility that the Convention is interpreted and applied as a lex specialis in deviation from what would ordinarily follow when interpreting the Convention through systemic integration. It may very well be, for example, that European human rights law as a particular branch of public international law contains rules of attribution which differ from those as laid down in general international law on State responsibility and that this is recognized through the Court's case law. This possibility is clearly contemplated by Article 55 ARSIWA which provides that the rules of ARSIWA (incl. those on attribution) do not apply where and to the extent that special rules of international law provide otherwise. In that sense, the Articles are not only general, they are also residual, ${ }^{39}$ being applicable only insofar as they are not deviated from in primary rules of international law. The tension between a harmonious and an autonomous interpretation of the Convention is very much present in the Court's case law. ${ }^{40}$ While this tension may be unavoidable, it becomes problematic when the Court does not express which path it follows and this has been another source of confusion with respect to State responsibility in extraterritorial situations and/or those involving non-State actors.

37 Loizidou v. Turkey (Preliminary Objections), ECtHR Application No. 15318/89, Judgment of 21 March 1995, para. 70. See also e.g. Mamatkulov and Askarov v. Turkey, ECtHR Applications Nos. 46827/99 and 46951/99, Judgment of 4 February 2005, para. 100.

38 Loizidou (Preliminary Objections), supra note 37, para. 75. See also e.g. Al-Skeini, supra note 5 , para. 141.

39 Introduction to Commentaries, in Crawford, Commentaries, supra note 4, 76, para. 5.

40 See e.g. Avsar v. Turkey, ECtHR Application No. 25657/94, Judgment of 10 July 2001, para. 284, where the Court held that responsibility under the Convention "is based on its own provisions which are to be interpreted and applied on the basis of the objectives of the Convention and in light of the relevant principles of international law" (emphasis added). 
For a State to be held responsible under the Convention for the conduct of its officials or agents, an express or implied determination of attribution is not the end of the matter, though. State responsibility requires also that the relevant conduct is contrary to what the substantive provisions of the Convention demand from the State as the addressee of its norms. Especially for conduct undertaken abroad, the preliminary question is whether the Convention applies at all. This is a matter of State jurisdiction in the sense of Article 1 of the Convention.

\section{Jurisdiction of the State under Article 1 of the Convention}

The Convention constitutes a binding engagement for those States that have ratified it. Yet, it does not necessarily follow that each and every action of the States Parties is subject to the constraints imposed by it. One needs to make a distinction between the binding nature of the Convention as a result of a State ratifying it and the applicability of the Convention to a particular set of circumstances. ${ }^{41}$ The Convention provides in Article 1 that the States Parties shall secure to everyone "within their jurisdiction" (in the French text: "relevant de leur jurisdiction") the rights and freedoms defined in Section I. ${ }^{42}$ Consequently, the Convention can only be relied on when it is shown that the victim was within the State's jurisdiction. As the Court has held repeatedly: "The exercise of jurisdiction is a necessary condition for a Contracting State to be able to be held responsible for acts and omissions imputable to it which give rise to an allegation of the rights and freedoms set forth in the Convention." ${ }^{33}$ Put differently, Article 1 is a

41 Cf. Report of the Study Group of the International Law Commission (Finalized by Martti Koskenniemi), Fragmentation of International Law: Difficulties Arising from the Diversification and Expansion of International Law, UN Doc A/CN.4/ L.682 (13 April 2006), 30, para. 46, fn. 48, which makes a distinction between the validity of a rule of international law and the applicability thereof. A rule is valid if it is part of the legal order, while to say that a rule is applicable means that it "provides rights, obligations or powers to a legal subject in a particular situation". In the context of the Convention, the former would be a matter of ratification and entry into force and the latter a matter of State jurisdiction under Article 1.

42 With respect to the Optional Protocols to the Convention, Article 1 applies mutatis mutandis.

43 See e.g. Ilaşcu and Others v. Moldova and Russia, ECtHR Application No. 48787/99, Judgment of 8 July 2004 [GC], para. 311. 
"threshold criterion", 44 the meaning of which is determinative of the scope and reach of the Convention..$^{45}$ If the threshold is met, it triggers the application of the Convention to the particular circumstances of the case. In this sense, European human rights law bears similarities with international humanitarian law given that the latter also knows a threshold of application, i.e. the existence of an international or a non-international armed conflict. While all States Party to the Geneva Convention and its Additional Protocols are bound by its provisions from the moment of ratification and entry into force, the bulk of its provisions become applicable when the threshold has been met. ${ }^{46}$

The concept of State jurisdiction under Article 1 is underpinned by two presumptions. The first holds that everybody within a State's territory falls within its jurisdiction. The second presumption entails that a State's jurisdiction does not extend outside its national territory. However, the principle of territoriality and the lack of extraterritorial application must be qualified to account for the fact that jurisdiction is not "equivalent to or limited to" the territory of the States parties. ${ }^{47}$

\section{A. The Principle of Territoriality: Scope and Exceptions}

In principle, everyone within a State's own territory (including non-nationals) is presumed to be within a State's jurisdiction in the sense of Article $1 .{ }^{48}$ Here the State must secure the whole range of rights and freedoms provided for by the Convention. This encompasses both the negative obligation to abstain from violating rights as well as the positive obligation to

44 Al-Jedda v. the United Kingdom, ECtHR Application No. 27021/08, Judgment of 7 July 2011 [GC], para. 74.

45 Banković, supra note 36, para 65.

46 On the relationship between State responsibility law and the classification of armed conflicts, see further R. Jorritsma, Where General International Law Meets International Humanitarian Law: Attribution of Conduct and the Classification of Armed Conflicts, 23 Journal of Conflict \& Security Law (2018), 405.

47 Cyprus v. Turkey (I/II), ECtHR Applications Nos. 6780/74 and 6950/75, Decision of 26 May 1975.

48 Ilaşcu, supra note 43, para. 312. According to Article 56(1) of the Convention, a declaration by the State is required to extend the territorial reach of the Convention to any of the non-metropolitan territories for whose international relations it is responsible. An additional declaration by the State is required to recognize the Court's jurisdiction to receive individual applications, see Article 56(4) ECHR. 
prevent private actors from infringing upon the enjoyment of human rights of other individuals.

The presumption that the Convention applies in full throughout the whole of a State's territory is difficult to rebut. In the Assanidze case the Court examined whether Georgia could be held responsible for the acts of its local authorities. ${ }^{49}$ The case concerned the applicant's continued detention by the authorities of the Ajarian Autonomous Republic - a politicaladministrative region considered in domestic and international law as belonging to Georgia - following a conviction by Ajarian courts despite having received a pardon (for one offence) by the Georgian president and being acquitted (for another) by the Supreme Court of Georgia. The Court maintained the principle of territoriality and held that the applicant's detention fell within the jurisdiction of Georgia despite the fact that in the autonomous region the State "encounter[ed] difficulties in securing compliance" with the Convention. ${ }^{50}$ Thus, mere autonomy of a part of the territory of a State is not sufficient to displace the principle of territoriality or the full application of the Convention.

In principle, the Convention also continues to apply (with individuals continuing to be within its jurisdiction) when a State has lost control or authority over part of its territory to a third State, for example, as a result of belligerent occupation, the presence of military bases of foreign troops, or local insurgents with a secessionist agenda who are controlled by a foreign State. However, in these situations the range of the Convention's substantive obligations is limited in light of the exceptional circumstances that the territorial State finds itself in. Rather than having to ensure the whole of the Convention, the territorial State is merely under a positive obligation to secure the rights guaranteed by the Convention through "diplomatic, economic, judicial or other measures that it is in its power to take and are in accordance with international law" ${ }^{11}$ This positive obligation encompasses two limbs, namely, the obligation to take appropriate diplomatic,

49 Assanidze v. Georgia, ECtHR Application No. 71503/01, Judgment of 8 April 2004 [GC]. See also Sargsyan v. Azerbaijan, ECtHR Application No. 40167/06, Judgment of 16 June 2015, paras. 132-151. In this case the Court applied its reasoning from Assanidze to the deserted village of Gulistan which was rendered practically inaccessible by surrounding minefields and the opposing forces of Azerbaijan and the Nagorno-Karabakh Republic. See further section V.C.3.

50 Assanidze, supra note 49, para. 146.

51 Ilaşcu, supra note 43, para. 331. See also Ivanţoc and Others v. Moldova and Russia, ECtHR Application No. 23687/05, Judgment of 15 November 2011, paras. 105-111; Catan and Others v. Moldova and Russia, Nos. 43370/04, 8252/05 and 18454/06, Judgment of 19 October 2012 [GC], paras. 145-148; Mozer v. Moldova 
economic and legal measures (1) to re-establish control over its territory (including the obligation to refrain from supporting the State or entity which controls the territory), and (2) to ensure respect for the human rights for those situated in that territory.

Matters become more complicated outside a State's own territory. As warned by former Court President Luzius Wildhaber, "the Convention was never intended to cure all the planet's ills and indeed cannot effectively do so". 52 At the same time, legal considerations sustain the argument that a State cannot be allowed to do abroad what it is prohibited from doing on its own territory. The Convention must therefore be interpreted and applied in a way that balances the legitimate interests of States as well as individuals. Such an interpretation would recognize that States have obligations in respect of situations abroad but only when this would be reasonable in light of the specific facts of a case.

Early decisions on the admissibility of individual complaints were indicative of the potential for the Convention to apply extraterritorially. In Hess, for example, it was held that "in principle, from a legal point of view, [there is] no reason why acts of the British authorities in Berlin should not entail the liability of the United Kingdom under the Convention". ${ }^{33} \mathrm{Al}-$ though the application was declared inadmissible, this statement of principle demonstrates that while the scope of a State's jurisdiction is primarily territorial it is not exclusively so, ${ }^{54}$ albeit that extraterritorial application remains, even today, an exceptional matter. ${ }^{55}$ Looking at the Court's case law in retrospect it is possible to discern that the extraterritorial application of the Convention has crystalized along the lines of two models: the personal

and Russia, No. 11138/10, Judgment of 23 February 2016 [GC], paras. 151-155. These cases dealt with events occurring within Transnistria, a Moldavian unrecognized region with secessionist aspirations, controlled or at least substantially supported by Russia. See further section V.C.2.

52 Speech given by President Luzius Wildhaber on occasion of the opening of the judicial year of the Court, Strasbourg, 31 January 2002, quoted in R. Lawson, Life After Banković: On the Extraterritorial Application of the European Convention on Human Rights, in Coomans and Kamminga, supra note 3, 83, 116.

53 See e.g. Hess v. the United Kingdom, ECtHR Application No. 6231/73, Decision of 28 May 1975 [Cion.].

54 See also Legal Consequences of the Construction of a Wall in the Occupied Palestinian Territory, Advisory Opinion, ICJ Reports 2004, 136, 179, para. 109: "[W]hile the jurisdiction of States is primarily territorial, it may sometimes be exercised outside the national territory.".

55 Al-Skeini, supra note 5, para. 132. 
model and the spatial model. ${ }^{56}$ To be applied, both models do not require that the conduct abroad takes place in the territory of another State Party to the Convention. ${ }^{57}$

\section{B. State Jurisdiction under the Personal Model}

Under the personal model, extraterritorial jurisdiction is established on the basis of the legal or factual relationship between the State and the individual who is alleged to be the victim. The relevant test is whether an individual is under a State's "authority and control through its agents operating ... in [another] State". ${ }^{58}$ The Court's case law offers a number of scenarios in which such authority or control exists even though it must be admitted that the precise outer limits of this category remain uncertain, in particular when such authority or control is exercised from a distance.

When a State exercises de jure authority outside of its national territory, based on a treaty or other source of international law, the personal model is applicable in relation to persons affected by such authority. Such is the case for diplomatic and consular agents in a host State. When a State exercises diplomatic functions in relation to individuals acting through its agents (e.g. by granting them passports, providing consular assistance in carrying out a court order of the sending State, bringing about their expulsion from the host State, or handing them over to the latter's authorities), these individuals are considered to be within the sending State's extraterritorial jurisdiction. One of the earliest manifestations of the personal model on this ground can be found in a 1965 decision by the Commission when a German national complained that German diplomatic and consular staff in Morocco had requested the local authorities to expel him from the

56 See also W.A. Schabas, The European Convention on Human Rights: A Commentary (2015), 101-104; L. Caflisch, Attribution, Responsibility and Jurisdiction in International Human Rights Law, 10 Anuario Colombiano de Derecho Internacional (2017), 161, 164; Council of Europe, Guide on Article 1 of the European Convention on Human Rights (updated 30 April 2018), para. 16, available at www.echr.coe.int (Case-law - Case law guides).

57 Al-Skeini, supra note 5, para. 142. This is a departure from Banković, supra note 36 , para. 80 , in which the Court suggested that the Convention applies in an "essentially regional context" and that extraterritorial application was in any case limited to the legal space (espace juridique) that comprises the sum of the territory of the States Parties.

58 This formulation was used for the first time in Issa and Others v. Turkey, ECtHR Application No. 31821/96, Judgment of 16 November 2004, para. 71. 
country. Deciding on the admissibility of the complaint, the Commission held that "in certain respects, nationals of a Contracting State are within its 'jurisdiction' even when domiciled or resident abroad" and that such is the case "in particular [when] the diplomatic and consular representatives of their country of origin perform certain duties with regard to them". ${ }^{59}$ Other recognized exercises of sovereign authority based on international law are judges sitting outside a State's territory but applying their own national laws, ${ }^{60}$ or the operation of State schools abroad. ${ }^{61}$

Next to the exercise by a State of sovereign, or de jure, authority, the personal model also covers situations of de facto control, or physical power. A common denominator here is that the victim's freedom of movement was controlled, restricted or negated due to the actions of State agents therefore bringing the individual and his/her subsequent treatment (such as the infliction of harm, ${ }^{62}$ or the transfer to a third State ${ }^{63}$ ) within the State's jurisdiction. One example is the deprivation of liberty due to arrest or detention in the context of law enforcement operations. Thus, when France apprehended and took into custody a suspect of terrorism in Sudan, the Commission had little difficulty to find that, from the time of being handed over to its agents, the applicant was within French jurisdiction. ${ }^{64}$ With

59 X v. Federal Republic of Germany, ECtHR Application No. 1611/62, Decision of 25 September 1965 [Cion]. While there are exceptions - e.g. restrictions on the political activities of aliens (Article $16 \mathrm{ECHR}$ ) or the prohibition of expulsion of nationals (Article 3 Optional Protocol 4) - the enjoyment of the rights and freedoms of the Convention generally does not depend on the nationality of the victim. Consequently, the Commission was right to drop the reference to "nationals" in subsequent cases involving the (extraterritorial) application of the ECHR. For other cases involving diplomatic and consular agents, see X. v. the United Kingdom, ECtHR Application No. 7547/76, Decision of 15 December 1977 [Cion]; M. v. Denmark, ECtHR Application No. 17392/90, Decision of 14 October 1992 [Cion].

60 Cf. Drozd and Janousek v. France and Spain, ECtHR Application No. 12747/87, Judgment of 26 June 1992.

61 Gentilhomme, Schazff-Benhadji and Zerouki v. France, ECtHR Applications Nos. 48205/99, 48207/99 and 48209/99, Judgment of 14 May 2002.

62 Issa, supra note 58. The Court ultimately did not find sufficient evidence for the involvement of Turkish soldiers. However, had such involvement been established as a matter of fact, the victims would have been within Turkish jurisdiction as a result of the soldier's control and authority over them. This interpretation is confirmed in Al-Skeini, supra note 5, para. 136.

63 Al-Saadoon and Mufdhi v. the United Kingdom, ECtHR Application No. 61498/08, Decision of 30 June 2009.

64 Sánchez Ramirez v. France, ECtHR Application No. 28780/95, Decision of 24 June 1996 [Cion]. 
respect to the apprehension of Abdullah Öcalan by Turkish security forces in Kenya, the same conclusion was reached by the Court. ${ }^{65}$ Another form of liberty deprivation is internment or detention in times of international ${ }^{66}$ or non-international armed conflict. ${ }^{67} \mathrm{~A}$ third form of deprivation of liberty giving rise to the extraterritorial application of the Convention occurs when a State's maritime forces board and assume control over an intercepted vessel ${ }^{68}$ or when the vessel's personnel is transferred to the intercepting ship. ${ }^{69}$

When it comes to the exercise of physical power without prior arrest or detention, however, the picture becomes less clear. In its case law, the Court appears to take the distance between the victim and the State agent using force as an important criterion. The Court held in Bankovic that the victims of an aerial bombardment were not within the jurisdiction of the States involved. ${ }^{70}$ The bombardment was carried out from a minimum altitude of 15000 feet by States participating in Operation Allied Force during the Kosovo war. Subsequent cases appear to have gradually departed from the narrow interpretation of State jurisdiction in Banković. In Isaak, for instance, the Court accepted the extraterritorial application of the Convention to a person who was beaten to death by Turkish agents in the neutral United Nations (UN) buffer zone separating Greek-Cyprus from TurkishCyprus. ${ }^{71}$ In Jaloud and Pisari, the Court applied the personal model to individuals who were taking fire when approaching or passing through vehicle checkpoints. ${ }^{72}$ And in Pad, the Court appeared to entertain the possibility that the killing of individuals through helicopter gunfire on foreign ter-

65 Öcalan v. Turkey, ECtHR Application No. 46221/99, Judgment of 12 May 2005 [GC].

66 Al-Saadoon and Mufdhi, supra note 63 (concerning detention which started during the occupation of Iraq); Hassan v. the United Kingdom, ECtHR Application No. 29750/09, Judgment of 16 September 2014 [GC] (concerning detention which took place in Iraq during active hostilities in the invasion stage).

67 Al-Jedda v. the United Kingdom, ECtHR Application No. 27021/08, Judgment of 7 July 2011 [GC].

68 Medvedyev and Others v. France, ECtHR Application No. 3394/03, Judgment of 29 March 2010 [GC].

69 Jamaa and Others v. Italy, ECtHR Application No. 27765/09, Judgment of 23 February 2012 [GC].

70 Banković, supra note 36 , para. 82.

71 Isaak v. Turkey, ECtHR Application No. 44587/98, Judgment of 24 June 2008.

72 Jaloud v. The Netherlands, ECtHR Application No. 47708/08, Judgment of 20 November 2014 [GC]; Pisari v. Moldova and Russia, ECtHR Application No. 42139/12, Judgment of 21 April 2015. See also Al-Skeini, supra note 5, in which all six victims were considered as being within the jurisdiction of the United 
ritory brought the victims within the respondent State's jurisdiction. ${ }^{73}$ In this case, Turkey admitted that the fire discharged from its helicopters had caused victims but denied that this took place in Iranian territory. Accordingly, the Court did not find it necessary to determine the exact location of the attack. That said, the Court's assessment of case law on extraterritorial application strongly suggests that the outcome of the case would be the same had it actually been proven that the acts took place on Iranian soil. ${ }^{74}$

One particular variation to extraterritorial application concerns cross-border situations in which a State acts on its own territory but produces (or has the potential to produce) effects abroad. In the Soering case, the Court held that a State Party would violate the Convention if it deports an individual to any other State where the individual would run a substantial risk of torture or inhuman or degrading treatment. ${ }^{75} \mathrm{~A}$ second cross-border case is Andreou, in which the applicant, while standing in Greek-Cypriot territory, was shot by Turkish agents in Turkish-Cypriot territory. The Court held that even though the applicant sustained her injuries in territory over which Turkey exercised no control, "the opening of fire on the crowd [took place] from close range [and] was the direct and immediate cause of those injuries", such that the applicant was within Turkish jurisdiction. ${ }^{76}$ These two cases are not concerned with extraterritorial application in the traditional sense. ${ }^{77}$ After all, the decision to deport or open fire on someone is taken within a State's own territory. Nevertheless, it remains true that the State exercises control over the individual by having a decisive effect on his/her enjoyment of human rights; the individual has no free will in the matter, similar to the cases of interception, arrest and detention as mentioned above. Yet these cases cause one to wonder how the Court would decide on cross-border situations in which there is a comparable causal link between the use of force and the injuries sustained but with a

Kingdom under the personal model, even though four of them had died in the course of security operations without a prior arrest or detention.

73 Pad and Others v. Turkey, ECtHR Application No. 60167/00, Decision of 28 June 2007.

74 If the location of the attack had been a decisive factual element in the case, one would have expected the Court to look closer into this. After all, the Court must decide, if necessary on its own motion, whether it has in fact jurisdiction, and whether the case is admissible ratione personae and ratione loci.

75 Soering v. the United Kingdom, ECtHR Application No. 14038/88, Judgment of 7 July 1989.

76 Andreou v. Turkey, ECtHR Application No. 45653/99, Decision of 3 June 2008 (emphasis added).

77 Banković, supra note 36, paras. 67-68. 
less close range (e.g. through cross-border sniper fire, artillery fire or even ballistic missiles).$^{78}$ It is furthermore questionable that a distinction is made between force being used in a cross-border context and air-to-surface force that is carried out wholly abroad. Future cases will hopefully clarify to what extent the Banković decision still reflects today's law and the role proximity and causality play in the establishment of extraterritorial State jurisdiction. As the High Court of England and Wales reasoned, when the lesser use of force of apprehending someone suffices for jurisdiction under Article 1, "it makes no sense to hold that the greater use of force involved in killing someone does not have that effect". 79

In any event, as confirmed in Al-Skeini, the application of the personal model to extraterritorial conduct qualifies the extent of substantive obligations imposed on the State. Even though the victim abroad may be within the reach of the Convention for the purpose of Article 1, it is not necessary for the State to secure the whole catalogue of rights and individual freedoms; the range of rights and freedoms is proportionate to the level of control. It is, for example, appropriate to expect the State to refrain from violating the right to life or the prohibition of torture whereas certain positive obligations, such as to ensure the right to education or the freedom of assembly, are less likely to be applicable to persons finding themselves in such situations. Hence, contrary to the Court's all-or-nothing approach in Banković, the Convention rights can be "divided and tailored" with the effect that only those rights and freedoms that are relevant to the situation of an individual come into play. ${ }^{80}$

7878 Cf. Al-Skeini, supra note 5, Concurring Opinion of Judge Bonello, para. 14: "I resist any helpful schizophrenia by which a nervous sniper is within the jurisdiction, his act of shooting is within the jurisdiction, but then the victims of that nervous sniper happily choke in blood outside it."

See in the same vein Assanidze, supra note 49, Concurring Opinion of Judge Loucaides, arguing that jurisdiction means "the possibility of imposing the will of the State on any person". See also Caflisch, supra note 56, 194, noting that a State sending troops abroad exercises jurisdiction whenever its troops "are in control of [a] specific event or situation" (emphasis in original).

79 Al-Saadoon and Others v. Secretary of State for Defence, [2015] EWHC 715 (Admin.), 17 March 2015, para. 107 (per Justice Leggatt).

80 Al-Skeini, supra note 5, para. 137. Cf. Banković, supra note 36, para 75. 


\section{State Jurisdiction under the Territorial Model}

Under the territorial, or spatial, model, the State's exercise of control is relevant as well, but here control exists in relation to an inanimate object, territory, as opposed to a human being. It is established case law that a State's jurisdiction extends when, as a consequence of military action, it exercises control over territory beyond its national borders. For this particular type of extraterritorial application of the ECHR, it is irrelevant whether the military action leading to territorial control is lawful or not, or whether the State claims title to that territory. ${ }^{81}$

A paradigmatic form of extraterritorial control of territory is belligerent occupation. According to Article 42 of the 1907 Hague Regulations, territory is considered occupied "when it is actually placed under the authority of the hostile army [and] extends only to the territory where such authority has been established and can be exercised".82 There is wide agreement that occupation requires the fulfilment of three specific conditions: (1) presence of foreign troops who exercise effective control over the territory, (2) substitution of their authority for that of the territorial State, and (3) lack of valid consent by the territorial State. ${ }^{83}$

The classical example of occupation is where a State's armed forces exercise territorial control so as to constitute an occupying power. ${ }^{84}$ Less straightforward, however, are situations that are not "classical" occupations

81 See also Legal Consequences for States of the Continued Presence of South Africa in Namibia (South West Africa) notwithstanding Security Council Resolution 276 (1970), Advisory Opinion, ICJ Reports 1971, 16, 54, para. 118: "Physical control of a territory, and not sovereignty or legitimacy of title, is the basis of State liability for acts affecting other States." See also L.A. Raible, Title to Territory and Jurisdiction in International Human Rights Law: Three Models for a Fraught Relationship, 31 LJIL (2018), 315.

82 Article 42 Convention (IV) respecting the Laws and Customs of War on Land and its annex: Regulations concerning the Laws and Customs of War on Land, 18 October 1907, 36 Stat. 227 (1907). This provision represents customary international law, see e.g. Wall Advisory Opinion, supra note 54, 167, para. 78, and 172, para. 89; Sargsyan, supra note 49, paras. 94 and 144.

83 See e.g. Armed Activities, supra note 27, 230, para. 173; T. Ferraro, Determining the Beginning and End of an Occupation Under International Humanitarian Law, 94 International Review of the Red Cross (2012) 133, 143. As a matter of law, it cannot be ruled out that the Convention applies extraterritorially to forms of territorial control other than occupation, see Jaloud, supra note 72, para 141-142.

84 Cases such as Al Saadoon and Mufdhi, Al-Skeini, and Hassan show that if a person is wounded or killed by a State in the course of security operations or detention, the Court is more likely to apply the personal model rather than assessing 
in the sense of continued presence of a State's own armed forces. A State's armed forces may initially be present on and control the territory but subsequently withdraw after transferring its authority and control to a (pre-existing or newly put in place) local administration. Alternatively, a State may, without ever having had its own "boots on the ground", control or otherwise support a non-State actor which in turn can be said to exercise territorial control on the State's behalf. These situations have proven to pose difficulties - in particular because the question of occupation (or other forms of territorial control) and consequently the extraterritorial application of the Convention is often intrinsically tied to the question of attribution. Some of these situations were the subject of proceedings before the Court, notably in cases involving Northern Cyprus (with respect to the extraterritorial jurisdiction and responsibility of Turkey), Transnistria (with respect to that of Russia), and Nagorno-Karabakh and the Lachin district (with respect to that of Armenia).

\section{Northern Cyprus}

In Loizidou v. Turkey, the Court introduced the territorial model for the first time. The applicant in the case, Ms Loizidou, was owner of a number of plots of land located in Northern Cyprus. Following the Turkish invasion and subsequent occupation in 1974, she fled to the southern part of the island. She claimed that she was prevented from returning to enjoy her property, allegedly in violation of Article 8 of the Convention (right to respect for family and private life) and Article 1 of the First Optional Protocol (protection of property). In the Preliminary Objections phase the Court considered the argument by Turkey that the matters complained of did not fall within the latter's jurisdiction in the sense of Article 1 of the Convention. According to Turkey, its forces were present in Northern Cyprus to act on behalf of the Turkish Republic of Northern Cyprus (TRNC), and consequently the exercise of public authority must be seen as that of TRNC and not as imputable to Turkey. The Court did not follow Turkey's argument that the applicant was not in its jurisdiction. Interpreting Article 1 of the Convention, the Court held that:

[T] he concept of "jurisdiction" [under Article 1 of the Convention] is not restricted to the national territory of the High Contracting Parties.

whether the victim falls within that State's jurisdiction under the spatial model, e.g. as a result of the State being an occupying power. 
$[\ldots][T]$ he responsibility of a Contracting Party may also arise when as a consequence of military action - whether lawful or unlawful - it exercises effective control of an area outside its national territory. The obligation to secure, in such an area, the rights and freedoms set out in the Convention derives from the fact of such control whether it be exercised directly, through its armed forces, or through a subordinate local administration. ${ }^{85}$

Given that Turkey had acknowledged that the applicant's loss of access to her property was caused by its forces during the occupation of Northern Cyprus and the establishment therein of the TRNC, the Court held that "such acts are capable" of falling within Turkey's jurisdiction within the meaning of Article $1 .{ }^{86}$ Accordingly, it rejected Turkey's objection ratione loci, while explicitly reserving for the merits the specific question whether the matters complained of could be attributed to Turkey and give rise to State responsibility under the Convention.

In its judgment on the merits the Court recalled its earlier findings that, "in conformity with the relevant principles of international law governing State responsibility", effective control of an area is constitutive of State jurisdiction. ${ }^{87}$ Focusing on whether Turkey could be held responsible under the Convention for the acts of the TRNC, the Court added:

It is not necessary to determine whether [... Turkey actually exercised detailed control over the policies and actions of the authorities of the "TRNC". It is obvious from the large number of troops [...] in Northern Cyprus that her army exercises effective overall control over that part of the island. Such control [...] entails her responsibility for the policies and actions of the "TRNC". [...] Her obligation to secure to the applicant the rights and freedoms set out in the Convention therefore extends to the northern part of Cyprus. ${ }^{88}$

The Court concluded its consideration of this issue by holding that the applicant's loss of access to her property fell within Turkish jurisdiction and was "thus imputable to Turkey". 9

85 Loizidou (Preliminary Objections), supra note 37, para. 62.

86 Ibid., para. 64.

87 Loizidou v. Turkey (Merits), ECtHR Application No. 15318/89, Judgment of 18 December 1996, para. 52.

88 Ibid., para. 56 (references omitted). Here the Court speaks of "effective overall control", instead of "effective control" over territory, as it did earlier in the preliminary objections phase.

Ibid., para. 57. 
These two judgments in the Loizidou case are exemplary for the confusing way in which the Court treats the concepts of attribution and (State) jurisdiction as well as the relationship between them. To some extent this uncertainty flows from the Court's approach of seeking to divorce questions of procedure (admissibility and jurisdiction) from substance (the merits of the case). When the Court assesses the question of extraterritorial application such an inquiry often demands an in-depth legal appreciation of both the specific factual circumstances of the case and the various actors involved. Given that it is difficult to see the question of jurisdiction and admissibility as conceptually and analytically distinct from the merits, a better approach would have been to join these objections to the merits and decide on both in a single judgment. ${ }^{90}$ Instead, in the preliminary objections phase the Court applies the law of State responsibility in order to determine, at a procedural level, the existence of jurisdiction, while in the merits phase, at the substantive level, it appears as if the responsibility of Turkey for the acts of the TRNC follows from the existence of jurisdiction. The circularity of this reasoning is exacerbated by the use of imprecise language, for instance, that "responsibility ... may arise", without explaining whether this refers to an obligation under the primary rules of the Convention, jurisdiction in the sense of Article 1, or State responsibility proper under the secondary rules of ARSIWA in the sense of having committed an internationally wrongful act. ${ }^{91}$ Related to this, it is rather unclear whether the Court is holding Turkey directly responsible for the acts of the TRNC as a non-State actor or instead for its failure to exercise due diligence in

90 See e.g. Loizidou (Preliminary Objections), supra note 37, Joint Dissenting Opinion of Judges Gölcüklü and Pettiti, arguing that the Court could not rule on Article 1 jurisdiction without examining the de jure and de facto situation in northern Cyprus as to the merits. See also Pad, supra note 73, para. 50, reflecting the applicants' argument that the burden of proving, at the admissibility stage, the involvement of Turkey's agents within the territory of Iran would be "tantamount to having to prove the merits of the case as a precondition to establishing jurisdiction". In the majority of subsequent cases on extraterritorial application, objections ratione loci and/or ratione personae are now joined with the consideration of the merits.

91 The diverging use and meaning of the word "responsibility" is not unique to the European human rights system. Consider, among many examples, the doctrine of Responsibility to Protect, as articulated in the 2005 World Summit Outcome (GA Res. 60/1 of 16 September 2005, paras. 138-139), which employs the word responsibility in the meaning of obligation in the sense of a primary rule of international law. See also Responsibilities and Obligations of States Sponsoring Persons and Entities with respect to Activities in the Area, Advisory Opinion, ITLOS Seabed Disputes Chamber, 1 February 2011, ITLOS Reports 2011, 10, 30-31, paras. 64-71. 
preventing the infringement of human rights by the TRNC (i.e. indirect responsibility). Thus, while the Loizidou judgments for the first time make clear that a State can be held responsible for breaches of the Convention if in the course of military action it comes to control foreign territory by acting through its forces or a subordinate local administration, the Loizidou judgments still fall short of clearly explaining how concepts such as attribution, jurisdiction and responsibility relate to each other.

In Cyprus v. Turkey (IV), the Court had an opportunity to clarify its earlier judgments in Loizidou. ${ }^{92}$ Citing with approval the broad statement of principle from the merits phase of Loizidou, the Court added that having "effective overall control over northern Cyprus", Turkey's "responsibility cannot be confined to the acts of its own soldiers or officials in northern Cyprus but must also be engaged by virtue of the acts of the local administration which survives by virtue of Turkish military and other support".93 On this basis, the Court found that the matters complained of fell within Turkish jurisdiction and "therefore entail[ed] its responsibility under the Convention. ${ }^{94}$ The Court added that a State's responsibility may also be engaged when its authorities "[acquiesce or connive] ... in the acts of private individuals which violate the Convention rights of other individuals within its jurisdiction".95

Given that the Court presents indirect responsibility as an alternative ground for State responsibility, its earlier mention of State responsibility for acts of the local administration which survives by virtue of Turkish support (i.e. TRNC) must be understood to be one of direct responsibility, namely, attribution of the acts of the TRNC to Turkey based on the existence of the latter's jurisdiction and its provision of support. Yet, this raises a number of questions. For example, what is the decisive factor that underpins this direct attribution? Is it the existence of Turkish extraterritorial jurisdiction as such? Or, rather, is it the status of the TRNC as a local administration, or as surviving by virtue of crucial Turkish support (i.e. TRNC as de jure or de facto State organ under Article 4 ARSIWA, or perhaps as an entity under the control of Turkey as per Article 8 ARSIWA)? And, more fundamentally, did attribution follow from jurisdiction, or was it rather that jurisdiction followed from attribution? By failing to explain in unequivocal terms the interaction between the concepts of attribution, juris-

92 Cyprus v. Turkey (IV), ECtHR Application No. 25781/94, Judgment of 10 May 2001.

93 Ibid., para. 77.

94 Ibid.

95 Ibid., para 81. 
diction and responsibility the northern Cyprus cases have laid a shaky foundation for the territorial model. Unfortunately, these precarious precedents were used in later cases that similarly involved military action, territorial control, and/or occupation.

\section{Transnistria}

Contrary to the factual circumstances underlying the North Cyprus judgments referred to above, the cases dealing with Transnistria concern a situation in which the troops of one State (USSR, now Russia) remain present on the territory of another (Moldova), following the latter's independence from the former. In June 1990, Moldova proclaimed its sovereignty and independence from the USSR. Following this, a separatist regime declared the independence of the unrecognized "Moldovan Republic of Transnistria" (MRT) - a region in the east of Moldova, bordering Ukraine. In November 1990, hostilities broke out between Moldovan forces and MRT separatists culminating in an armed conflict that lasted until July 1992 when a ceasefire agreement was signed. Both before and after the ceasefire agreement Russia's 14 ${ }^{\text {th }}$ Army remained present in MRT despite the Moldova's repeated requests to withdraw the troops and military equipment. The $14^{\text {th }}$ Army provided the separatists with arms and equipment and participated in the planning of military operations. Russia also sustained the separatist regime through various forms of political and economic support. Instead of Moldova, it was Russia and MRT forces that exercised effective control over MRT.

The complex situation of Moldova has given rise to a number of judgments. In each of these cases the applicants claimed, inter alia, that Russia was responsible for violations of the ECHR on account of its de facto control of Transnistria and the support given to the separatist regime established there. The applicants from the first case, Ilaşcu, were arrested in Tiraspol (the administrative capital of MRT) in June 1992 by a number of persons, some of whom were wearing the uniforms of the $14^{\text {th }}$ Army while others wore camouflage gear without insignia. They were detained, in turn, in MRT police headquarters and in the $14^{\text {th }}$ Army garrison headquarters until they were brought to stand trial before the "Supreme Court of the MRT", which sentenced them to the death penalty (for the first applicant) or substantial terms of imprisonment (for the other three applicants). Applicants complained that their detention, conviction, and subsequent treatment violated a number of provisions of the Convention, most notably Article 6 (right to a fair trial by a competent court) and Article 5 
(right to liberty and security). On the question of extraterritorial application, the Court found that:

[T] he "MRT", set up in 1991-92 with the support of the Russian Federation, vested with organs of power and its own administration, remains under the effective authority, or at the very least under the decisive influence, of the Russian Federation, and in any event [...] it survives by virtue of the military, economic, financial and political support given to it by the Russian Federation. ${ }^{96}$

Consequently, the Court held that there is a "continuous and uninterrupted link of responsibility" on the part of Russia, ${ }^{97}$ with the result that the applicants fell within the latter's extraterritorial jurisdiction. Without much elaboration, the Court confirmed this finding of extraterritorial jurisdiction by Russia over the MRT in a later judgment involving the continued detention of two of the applicants from the Ilaşcu case, despite the Court's ruling in that case that the respondent States should ensure their release. ${ }^{98}$

Another case dealing with Russia's responsibility for events taking place in MRT is Catan. In this case, applicants complained, inter alia, that Article 2 of the First Optional Protocol (right to education) had been violated when authorities of the MRT forced their school to be closed down, due to the education being offered using the Latin alphabet rather than the Cyrillic script that was required by the MRT. Russia argued that it did not exercise extraterritorial jurisdiction given that the territory in question was controlled by a de facto government which was not its "organ or instrument". However, according to the Court, even after the period concerning Ilaşcu, the MRT was able to continue in existence only because of Russia's support. In these circumstances, the Court held the "high level of dependency on Russia's support provides a strong indication that Russia exercised effective control and decisive influence over the 'MRT' administration during the period of the school's crisis", with the result that the applicants fell within the jurisdiction of Russia. ${ }^{99}$ This finding with regard to Russia's jurisdiction was confirmed in Mozer, a later case involving the applicant's arrest and detention as ordered by MRT courts. ${ }^{100}$

96 Ilaşcu, supra note 43, para. 392 (emphasis added).

97 Ibid., para. 394.

98 Ivanțoc, supra note 43, paras. 116-120.

99 Catan, supra note 43, paras. 122-123.

100 Mozer, supra note 43, paras. 101-111. 
A significant distinction between Ilaşcu and Ivanțoc on the one hand, and Catan and Mozer on the other, is that in the latter cases there was no indication of any direct participation by Russian agents in the measures taken against the applicants. With respect to Russia's responsibility for the alleged acts, the Court sidestepped this by recalling its earlier case law, most notably Loizidou (Preliminary Objections), holding that for Russia to be internationally responsible it was not necessary that it exercise "detailed control over the policies and actions of the subordinate local administration", i.e. of the MRT. ${ }^{101}$

\section{Nagorno-Karabakh and Surrounding Districts}

Nagorno-Karabakh is a region situated within Azerbaijan, consisting for the most part of ethnic Armenians who wish to be unified with Armenia. On 2 September 1991, a few days after Azerbaijan declared itself independent from Soviet Union, the region of Nagorno-Karabakh announced the establishment of the secessionist Nagorno-Karabakh Republic (NKR). To date, the self-proclaimed independence of NKR is not recognized by the international community. In early 1992, Azerbaijan and Armenia were admitted to the UN. Around the same time, the conflict escalated into a fullscale war causing a large number of Azeris - the ethnic minority in NKR to flee from the area that by then had come under control of ethnic Armenian forces. This included not just NKR but also a number of surrounding territories, including the district of Lachin which lies in between NKR and the Armenian border.

The leading case arising out of this situation is Chiragov. In this case, applicants were among this group of internally displaced persons. Before the Court they complained that due to the occupation of the area by Armenia and/or Armenian-backed NKR forces, they were unable to return to their homes and property in Lachin, allegedly in breach of, inter alia, Article 1 of the First Optional Protocol. The Armenian government argued that the matter fell outside of the Court's competence ratione loci. Rejecting Armenia's argument, the Court followed its line of jurisprudence as set out in the Northern Cyprus and Transnistria cases. As a matter of fact, the Court established that Armenian had been significantly involved in the conflict, most notably through its military presence, the provision of military equipment and expertise, as well as various other forms of support given to

101 Catan, supra note 43, paras. 149-150. 
NKR. As a result, the Court held Armenia has "a significant and decisive influence of the 'NKR', and that the NKR and its administration "survives by virtue of the military, political, financial and other support given to it by Armenia which, consequently, exercises effective control" over the territories in question. ${ }^{102}$ Accordingly, the Court held that NKR and the surrounding territories fell under the jurisdiction of Armenia. ${ }^{103}$

\section{The Function of Attribution Rules in Determining State Responsibility under the Convention}

This final Section will demonstrate that the methodological pathway to address State responsibility for violations of the ECHR (including situations involving non-State actors and extraterritorial conduct) follows from the structure of ARSIWA itself. In the context of the Convention, it follows that a State will have committed an internationally wrongful act resulting in its responsibility when certain conduct is attributable to it, and if such conduct constitutes a violation of applicable provisions of the Convention. The two conditions of attribution and breach are cumulative; both need to be satisfied. More importantly, the presence of one condition does not suffice, nor does it entail that the other condition is met ipso facto. As a matter of law, the fact that conduct is attributable does not always mean that this conduct generates State jurisdiction. And conversely, the existence of State jurisdiction does not mean that all conceivable conduct taking place subject to that jurisdiction is that of the State.

In cases involving non-State actors in an extraterritorial setting the Court either conflates (or, at the very least, is unable to clearly demarcate) questions of attribution, jurisdiction, and State responsibility. ${ }^{104}$ One of the main uncertainties is to what extent attribution rules are relevant (or

102 Chiragov and Others v. Armenia, ECtHR Application No. 13216/05, Judgment of 16 June 2005 [GC], para. 186.

103 In Zalyan and Others v. Armenia, ECtHR Application Nos. 36894/04 and 3521/07, Judgment of 17 March 2016, para. 212-215, the Court explicitly endorsed its finding of Armenian extraterritorial jurisdiction. This case concerned allegations of torture and ill-treatment by Armenian officials of three individuals who were drafted in the Armenian army and assigned to serve in NKR. While it does not add anything to the reasoning as set out in Chiragov, the case is nonetheless noteworthy given that this is one of the few cases in which extraterritorial application based on the territorial model is applied towards an applicant vis-à-vis his own State.

104 See e.g. Milanović, supra note 3, 41-51; Gondek, supra note 3, 160-168. 
even decisive) as to the existence of personal or territorial State jurisdiction in the sense of Article 1. As early as 1965, in X v. Federal Republic of Germa$n y$, the Commission already held that the extraterritorial application of the Convention was the result of an assessment of two parameters: the question of the author of the act (here: consular and diplomatic agents), and the question of the material nature of the act that is claimed to be a violation of the provisions of the Convention (here: performing official duties). In light of this, it is worth returning to some of the cases falling in the personal model in which it was questionable whether the conduct complained of was attributable to the respondent State(s), to see how this affected the determination of extraterritorial application. These cases are most notably Drozd and Janousek, Behrami and Saramati, Al-Jedda, and Jaloud.

In Drozd and Janousek, the applicants had been convicted to a prison sentence by an Andorran court composed of Spanish and French judges. ${ }^{105}$ The applicants claimed inter alia that certain judicial irregularities during their trial did not conform to the requirements set by Article 6 of the Convention. After recalling its earlier case law on the extraterritorial application of the Convention, the Court held that "the question to be decided here is whether the acts complained of [...] can be attributed to France of Spain or both". 106 The Court answered this question in the negative because the French and Spanish judges had not acted as national agents but rather were put at the disposal of Andorra, to the effect that their acts were attributable to Andorra and not France and/or Spain. ${ }^{107}$ Thus, in order to assess whether the applicants were within the French or Spanish jurisdiction, the Court first turned to the issue of attribution; since the acts of the judges were not attributable to Spain or France (ratione personae), there was no extraterritorial jurisdiction from the point of view of those two States. A contrario, if a State brings an individual before its own judges, applying its own national law but sitting outside its territory (as happened for example with the Lockerbie/Pan Am Flight 103 trial, held in the Netherlands), such conduct would be attributable to the State and the persons affected by this would be within its jurisdiction. ${ }^{108}$

Al-Jedda concerned the internment of an Iraqi civilian in an Iraqi detention facility run by the United Kingdom, which was alleged to be in breach

105 Drozd and Janousek, supra note 60.

106 Ibid., para. 91.

107 See Article 6 ARSIWA.

108 This interpretation is confirmed in Al-Skeini, supra note 5, para 135. 
of Article 5 (1) of the Convention. ${ }^{109}$ Here too, the applicability of the Convention under Article 1 hinged on an assessment of attribution. The United Kingdom argued that the internment was attributable to the UN and that the applicant therefore was not within that State's jurisdiction. The Court did not follow the first part of this argument. On the basis of the facts of the case, as well as the text of Security Council Resolutions 1483, 1511 and 1546, the Court found that the Security Council had neither effective control nor ultimate authority and control over the acts of the troops of the Multinational Force (in which the United Kingdom participated). The result was that the applicant's detention was not attributable to the UN but to the respondent State and that consequently his detention fell within the latter's jurisdiction for the purpose of Article 1 of the Convention. The Court distinguished the situation at hand from its earlier decision in Behrami and Saramati and the mandate provided by Security Council Resolution $1244 .{ }^{110}$ In that case, the Court concluded that the conduct complained of (i.e. the failure by UNMIK - the UN Interim Administration Mission in Kosovo - to properly supervise de-mining as for Behrami, and detention by KFOR - Kosovo Force - as for Saramati) was exclusively attributable to the UN having ultimate authority and control, given that UNMIK was a subsidiary organ of the UN and that KFOR was exercising powers lawfully delegated under Chapter VII of the UN Charter. As a result of this exclusive attribution, the relevant conduct was not attributable to the States that contributed troops and the application was declared inadmissible ratione personae (obviating the need to entertain the parties' remaining Banković-inspired Article 1 arguments pertaining to the admissibility ratione loci).

Finally, in Jaloud the applicant complained that the Netherlands had violated the procedural limb of Article 2 of the Convention by not conducting an effective and independent investigation with respect to the use of deadly force against an individual who drove through a vehicle checkpoint. ${ }^{111}$ The Netherlands disputed that the events complained of fell within its jurisdiction. The vehicle checkpoint in question was located in the province of Al-Muthanna, Iraq. While the province as a whole and the Dutch contingent deployed there were under the operational command of an officer of the United Kingdom, the Netherlands was the only country to

109 Al-Jedda, supra note 44.

110 Behrami and Behrami v. France and Saramati v. France, Germany and Norway, ECtHR Applications Nos. 71412/01 and 78166/01, Decision of 2 May 2007 [GC].

111 Jaloud, supra note 72. 
provide security in the relevant area and it retained full command over its contingent. In light of this, and referring to Article 6 ARSIWA and paragraph 406 of the Bosnian Genocide case dealing with Article 8 ARSIWA, the Court found that the Dutch troops were neither placed at the disposal nor under the exclusive direction or control of any other State. As a result, the Court concluded that the death of the applicant's son took place within the jurisdiction of the Netherlands, having asserted authority and control over him.

Problematically, these early precedents, and the reasoning set forth in them, have been used in cases involving State control over territory without sufficiently grasping some essential differences between State control over person who claim to be victims and State control over territory. In situations where an individual abroad is held to be under the authority or control of agents of the State such as diplomatic and consular staff, members of the armed forces, the police, judges, etc, the material act that gives rise to the existence of extraterritorial jurisdiction (e.g. issuing passports, detention and ill-treatment, or the use of force at close range) is often the very same conduct (by the very same person) that constitutes the violation. Accordingly, a finding of attribution of the relevant conduct to the State concerned would also suffice to hold that this conduct took place in the exercise of that State's extraterritorial jurisdiction. Conversely, if in these cases a State could successfully claim that the material act was not attributable to it (ratione personae), it would by implication also be successful in demonstrating the lack of extraterritorial jurisdiction (ratione loci). ${ }^{112}$

In Jaloud, the Court argued that the test for establishing jurisdiction under Article 1 "has never been equated with the test for establishing a State's responsibility for an internationally wrongful act", 113 yet this is precisely what appeared to occur in that judgment (and the other three cases mentioned above). The applicants' arguments that they were within the jurisdiction of the respondent States was in effect approached by the Court as being in essence a question of attribution. In his concurring opinion, Judge Spielmann argued that attribution was irrelevant (a "non-issue") to decide the case at hand given that the main question was one of jurisdic-

112 This may explain why respondent States asserting that the applicant was not in their extraterritorial jurisdiction often do this by denying that the extraterritorial conduct is attributable to the State, i.e. by way of an objection ratione personae: see CoE Admissibility Guide, supra note 11, paras. 190 and 214 and cases cited there.

113 Jaloud, supra note 72, para. 154. 
tion under Article 1. ${ }^{114}$ This critique may go too far. As a matter of law and logic, their conceptually distinct nature does not imply that there is no relationship whatsoever between jurisdiction and attribution. While both questions are subject to different rules of law and different relationships, it does not necessarily follow that it is "ambiguous" or "incomprehensible" to examine attribution before turning to jurisdiction. After all, it is simply inconceivable that a certain act, such as detention, brings an individual within the jurisdiction of a State without that act being considered an "act of the State" in the first place. It is rather the Court's reluctance to engage in a closer examination of both concepts that has made its case law on this subject incomprehensible. ${ }^{115}$ On the other hand, Judge Spielmann is of course correct to assert that questions of jurisdiction are not the same as attribution. Indeed, rephrasing the question of jurisdiction as one of attribution (as the Court appeared to do in Drozd and Janousek, Behrami and Saramati, Al-Jedda, and Jaloud) could leave the erroneous impression that attribution of the conduct complained of is in any case sufficient for extraterritorial jurisdiction, which is certainly not the case. Not all attributable conduct gives rise to State jurisdiction as illustrated very well by cases where the applicability of the personal model hinges on the exercise of physical power rather than the exercise of sovereign authority (e.g. Bankovici16). After all, the question of attribution refers to the author of the act and not so much the material nature of the conduct. That said, the more the Court is willing to accept additional categories of material conduct that constitutes jurisdiction under the personal model, the smaller the gap that remains between conduct which is attributable and conduct which is constitutive of jurisdiction. Moreover, in cases of extraterritorial exercise of de jure governmental authority by State organs or entities empowered to exercise governmental authority (covered by Articles 4 and 5 ARSIWA), the questions of attribution and jurisdiction essentially come together.

In the spatial model of jurisdiction, things seem to be exactly the other way around. Here, an overarching problem in the Court's case law is the

114 Ibid., Concurring Opinion of Judge Spielmann joined by Judge Raimondi.

115 See also ibid., Concurring Opinion of Judge Motoc, para. 8, arguing that "while the present judgment makes progress as regards the applicability of general international law, questions concerning the relationship between general international law and the human rights provided for in Article 1 have still to be clarified".

116 In Banković, supra note 36, the governments disputed the extraterritoriality of the Convention based on the nature of the material acts (i.e. high altitude bombardment), without - except for the French government - claiming that the bombardments were not attributable to the States involved. 
inability to distinguish clearly between attribution of non-State actor conduct, the breach of a positive obligation to act, and effective jurisdictional control over territory. While the personal model suffers from the impression that attribution generates jurisdiction, the spatial model appears to imply that jurisdiction generates responsibility. This is difficult to understand, or at the least insufficiently explained by the Court, given that control over territory is something different from control over a perpetrator. As the International Court of Justice held in its first contentious case, territorial control exercised by a State does not make it responsible for any unlawful act occurring on such territory (and thus subject to its jurisdiction); such control "neither involves prima facie responsibility nor shifts the burden of proof" "117 But looking at some of the formulations used in the case law setting out the spatial model, it appears as if extraterritorial State jurisdiction implies responsibility for all that happens by the hands of the nonState actor (i.e. the administration of the TRNC, the MRT, or the NKR), even in the absence of the third State exercising detailed control over all their individual actions.

This apparent approach is problematic for at least two reasons. First, it is very difficult to discern any underlying justification for holding a State responsible for the actions of local entities when the Court speaks of "effective control or decisive influence" over the TRNC, the MRT, or the NKR as an area, instead of assessing the level of control or influence over the nonState actors as persons or entities as required by the standard set forth in Articles 4 ( $r e$ de facto organs) and 8 ARSIWA. A second, related, difficulty is the blurring of the line between attribution of conduct and the failure to exercise due diligence. Cases concerning Northern Cyprus, Transnistria and Nagorno-Karabakh often involve property claims protected under Article 1 of the First Optional Protocol. On this particular provision, the Court has held that even though "the boundaries between the State's positive and negative duties under Article 1 of Protocol No. 1 do not lend themselves to precise definition [the] applicable principles are nonetheless similar".118 Accordingly, in that case the Court focused on whether the State's conduct could be justified in view of the principles of lawfulness, legitimate aim and fair balance, regardless of whether that conduct could be characterized as an interference (i.e. an attributable act), or a failure to

117 Corfu Channel Case (Albania v. the United Kingdom), Judgment (Merits), 9 April 1949, ICJ Reports 1949, 4, 18.

118 Ališić and Others v. Bosnia and Herzegovina, Croatia, Serbia, Slovenia and "The Former Yugoslav Republic of Macedonia", ECtHR Application No. 60642/08, Judgment of 16 July 2014 [GC], paras. 101-102. 
act (i.e. an omission). The particular nature of property claims is another factor that makes extraterritorial application cases involving the spatial model difficult to understand. An examination of situations giving rise to the spatial model should take into account that the attribution of conduct (i.e. territorial control) that is said to generate jurisdiction is something different from the attribution of conduct (e.g. the use violence, improper judicial proceedings, etc) that is alleged to constitute the violation.

A final consideration relates to the lack of recognition or consideration of attribution rules. The Court displays a tendency of silently applying the principles underpinning ARSIWA but without expressly mentioning them, or, to misapply (e.g. through lowering the standard of attribution) or reject them without offering any justification. Given the wide acceptance of ARSIWA as general international law, and the inherent tension between the Court's practice of systemic integration and treating the Convention as a constitutional instrument of European public order, it is regrettable that the Court shows such a reluctance to expressly apply, or reject without motivation, ARSIWA's attribution rules in establishing State responsibility (and the preliminary questions whether conduct is attributable to a State for the purpose of establishing the applicability of the Convention and the existence of a breach strictu sensu). This is even more so because some of the language used by the Court - e.g. "effective overall control", or "effective control and decisive influence" - is remarkably close to the test of attribution as laid down in Article 4 (re de facto State organs) and Article 8. The cumulative effect of these issues is uncertainty and unpredictability, obscuring the legal foundation of the Court's reasoning. It also has the unfortunate side-effect of diminishing the Court's potential to clarify ARSIWA, to contribute to the crystallization into customary law of those ARSIWA rules which may not yet be deemed to have such status, or, rather, to demonstrate to what extent the Convention system provides for lex specialis in deviation from general international law.

\section{Conclusion}

The conceptual difference between the applicability of the Convention, and the responsibility for an act that occurs where and to whom the Convention is applicable, means that a finding of whether a State has committed a breach of the Convention actually involves a number of dimensions. The first is one of attribution. Attribution rules serve to tie conduct to an actor with international legal personality, in this case a State Party. But the fact that conduct is attributable says nothing about whether such conduct 
was lawful or not. This still depends on whether there is a breach of any applicable law. As far as the Convention is concerned, and unlike "ordinary" treaties concluded between States, ${ }^{119}$ this latter question actually comprises two sub-questions: the existence of State jurisdiction so as to make the treaty applicable in the first place, ${ }^{120}$ and the existence of a breach itself. ${ }^{121}$

The question of whether extraterritorial conduct by States or non-State actors leads to the existence of extraterritorial jurisdiction and the existence of a breach strictu sensu cannot be answered before one resolves the question of whether the relevant conduct is an "act of the State" in the first place. This is the domain of attribution rules. On the other hand, while it is true that the lack of attribution of conduct to a State precludes the existence of that State's jurisdiction abroad, it does not necessarily follow that the situation falls under Article 1, and thus under the scope of the Convention, if the relevant conduct is attributable. Furthermore, the fact that conduct abroad generates State jurisdiction says nothing per se about the attributability of acts taking place within its extraterritorial jurisdiction. By examining whether conduct constitutes State jurisdiction other than through ARSIWA's attribution rules (as happens in the territorial model), the Court merely invites the question as to the methodological underpinning of holding a State responsible for the actions of local entities abroad.

It would be interesting to see how the Court decides future cases on State responsibility in an extraterritorial setting. The Court will most certainly address these questions in a number of cases lodged in the context of the Russo-Georgian War (August 2008)122 and the Russo-Ukrainian War

119 As the Commission held in Cyprus v. Turkey (III), ECtHR Application No. 8007/77, Decision of 10 July 1978, para. 11: "These special obligations of a High Contracting Party are obligations towards persons within its jurisdiction, not to other High Contracting Parties.."

120 Article 13 ARSIWA and Article 1 ECHR.

121 Article 12 ARSIWA and Articles 2-18 ECHR.

122 See e.g. Georgia v. Russia (II), Application No. 38263/08, which concerns allegations of indiscriminate and disproportionate attacks by Russian forces and/or by the separatist forces under their control. On 13 December 2011, the Court joined to the merits of the case the Russian objection ratione loci that it did not exercise jurisdiction in South Ossetia, Abkhazia and the neighboring regions. Witness hearings were held in June 2016 and a hearing on the merits was held in May 2018. 
(2014 up to present). ${ }^{123}$ It is to be hoped that these cases put the legal appreciation of extraterritorial application on a more sound footing, keeping in mind the interaction between the Convention and general international law while not losing sight of the special nature of the Convention and the possibility of it providing for lege speciales rules on attribution and State responsibility.

123 See e.g. Ukraine v. Russia, ECtHR Application No. 20958/14 (on Russia's role in Crimea from March-September 2014); Ukraine v. Russia (IV), No. 42410/14 (Russia's role in Crimea after September 2014); Ukraine v. Russia (V), No. 8019/16 (Russia's role in Eastern Ukraine from March-September 2014); Ukraine v. Russia (VI), No. 70856/16 (Russia's role in Eastern Ukraine after September 2014). In May 2018 the Chamber dealing with the applications decided to relinquish jurisdiction over the cases in favour of the Grand Chamber. 